\title{
DELVING THE HOOK SENTENCE IN ARGUMENTATIVE ESSAY: FINDING THE WRITERS' PREFERENCES OF CATCHY SENTENCE
}

\author{
Yenni Arif Rahman \\ Universitas Bina Sarana Informatika \\ yeni.yar@bsi.ac.id
}

\begin{abstract}
Hook sentences as an opener and attention grabber in introductory paragraph play important role to make readers keep reading an essay. This means the structure and preferences to produce the hook is a key point to an interesting essay. The study aims to identify the writers' preferences to write hook sentences. The data were 40 argumentative essays collected from 7 different international newspapers and gazettes. The study employs content analysis procedure to analyze 4 related categories to preferences: theme, number of words, types of sentence, and types of hooks. The subcategories which consist of 13 items is created to supply the detailed preferences. The result shows that all 40 samples utilize theme-related hook, with 34 (85\%) samples written with more than 10 words, without dominant types of sentences (simple, compound, and complex), and with $23(58 \%)$ narrative or story hook. From the result, it can be inferred that the writers prefer hook-related theme with mostly narrative type hook. The result also shows that there is relatively fair preference between simple and complex sentence use.
\end{abstract}

Keywords: Hook Sentence; Argumentative Essay; Content Analysis

\begin{abstract}
ABSTRAK
Kalimat bait sebagai pembuka dan penarik perhatian dalam paragraph pembuka memainkan peranan penting untuk membuat pembaca meneruskan membaca sebuah esai. Hal ini berarti bahwa susunan dan preferensi penulisan kalimat bait adalah hal penting bagi sebuah esai. Penelitian ini bertujuan untuk mengidentifikasi preferensi penulisan kalimat bait oleh para penulis dalam esai. Data yang dipakai adalah sebanyak 40 samples hook dari esai-esai argumentatif yang dipublikaskan oleh 7 koran dan bulletin internasional. Penelitian ini menggunakan konten analisis prosedur untuk menganalisis 4 kategori yang berkaitan dengan preferensi penulis: tema, jumlah kata, tipe-tipe kalimat, dan tipe-tipe kalimat bait. Kategori tersebut kemudian dibagi menjadi 13 jenis subkategori yang berbeda untuk memberikan detail preferensi. Hasil menunjukkan bahwa semua 40 sampel menggunakan hook yang berkaitan dengan tema essay, dengan 34 (85\%) sampel ditulis menggunakan lebih dari 10 kata, tanpa salah satu tipe kalimat (sederhana, majemuk, komplek) yang dominan dalam penggunaan, dan dengan $23(58 \%)$ kalimat bait berjenis narasi. Dari hasil tersebut, disimpulkan bahwa penulis kalimat bait selalu berpreferensi dengan tema esai dan kalimat bait berjenis narasi lebih dominan digunakan. Hasil tidak menunjukkan adanya preferensi yang menonjol terhadap salah satu jenis kalimat: sederhana dan komplek.
\end{abstract}

Kata Kunci: Kalimat Bait, Esai Argumentatif, Konten Analisis

Submitted Apr 04, 2020 | Revised May 12, 2020 | Accepted May 16, 2020

\section{Introduction}

To present an argument in a structured manner, every essay more or less should contain the same things: introductory paragraph, body, and conclusion (Oshima \& Hogue, 2006. Bailey, 2011. Jordan, 2003). That generic structure of essay leaves the introduction as a forefront part to grab reader's attention in which at the same time it should inform the readers 
what will be covered in the essay. Thus, every good introductory paragraph always provides one or two sentences at the very beginning of them that pique the interest of the reader and these sentences are called the 'hook'(Hanski, 2019). It is represented by question, a quote, a surprising statistic or fact, or a strong statement highlighting the relevant of the topic (Buckham, 2014. Davis, 2019).

The central role of hook sentences as an attention grabber in introductory paragraph is no less important than thesis statement and interestingly thesis statement itself can perform as hook sentence (Buckham, 2014). This fact brings the limelight for hook sentence to study further in relation with the effective technique how to write this catchy sentence. Accordingly, there should be preferences of this attention grabber written by experienced writers as they must have some linguistics features as standards to write these hooks. These features are the theme, the length of sentences, the number of words contained within, and the types of hook themselves. These features then termed as categories in content analysis consist of some subcategories in which the writer preferences lie there.

The mapping of the hook preferences could give considerable contribution for the development of this subject in general. The result then can be a suggestive approach for student and writer to produce likable hook sentences that is appropriate with linguistic feature the essay they write. At the same time, it can be pedagogical approach and reference for the students and help them to replicate hook sentences according to suggested models. It will also provide them some guidance and tips how to write engaging hook sentences based on the patterns.

Switching to definition of essay, it is an analytic literary composition which deals with particular subject from personal poin of view (Merriam-Webster, 2019). So, it can be inferred that an essay is influenced by writer opinion to discuss an issue. Consequently, an essay is subjective and argumentative. Despite its subjectivity, the argument conveyed in the essay has to be logical, comprehensible, and based on theory or existing facts. By then it is not merely a fiction and imagination of the writer.

The hook sentence itself comes with many names like attention grabber or attention getter. By definition the hook sentences are an opening statement which can be the first or two sentences in the introductory paragraph of an essay to grab the attention of the readers so that they keep reading (Hills, 2018. Myers \& Wukash, 2009).

In further detail there are 14 types of hook sentences available. However, those 14 types can be generalized into six different types that represents the idea of hook sentence structure; they are: Question, Strong Statement, a Fact or Statistic, Metaphor or Simile, Story and Quotation hooks (Hills, 2018. Cascio, n.d.).

A question hook is an interesting question regarding the subject matter. It could be WH-question or confirmation question which need an answer or just a rhetoric one. This type of hook is effective to attract readers since it triggers readers curiosity about the answer of the question.

Strong statement is another type of hook which use assertive claim about a topic. A strong statement is a great technique because it doesn't matter if the readers agree or disagree with the statement. They will want to see how the writer support his or her statement.

Facts and statistics hook the reader because they give real information about a topic. They give knowledge and evidence from the very beginning of the essay. However, the writer needs to include facts that are accurate, interesting and reliable. In addition, the information must be evaluated to make sure it comes from a credible source.

A metaphor is a figure of speech that directly compares one thing to another, but these two things seem unrelated (Knowles, 2005. Punter, 2007). The metaphor or simile hook engages the readers because it makes them think about a topic in a different way. The audience wonders what it meant and how it compares a topic to something that seems unconnected by comparing the quality of character of both objects. 
Short story is a hook or episode that relates to the topic. It is a narration of the writer from their point of view. The key to a great story hook is making sure the story directly connects to the essay topic. The story can be personal or someone else's story.

Quotation is a hook where it begins to quote not only famous individual but also lay person. The hook can use quote if it connects to essay.

\section{Method}

The study employs content analysis which is a research method to analyze data, classify the patterns, and then interpreting its meaning in recorded communication e.g. newspaper (Schreier, 2012). To conduct content analysis, the researcher systematically collects data from written texts. Content analysis in this study are both quantitative (counting and measuring) and qualitative (focused on interpreting and understanding). In both types, the researcher categorizes or "codes" words, themes, and concepts within the texts and then analyze the results. As any successful content analysis, it always extract the data to the concepts that describe the research phenomenon (Hsieh \& Shannon, 1997). Then the concepts termed as categories aimed to find preferences across them: theme, number of words, types of sentences, and types of hook.

As any content analysis procedure, this study starts with a direct research question. What are the writers' preferences of hook sentences in argumentative essay? To answer that, content analysis provides 5 procedures to find the answer (Neuendorf, 2016. Krippendorff, 2013). These procedures should be orderly, must not be skipped or reversed. The previous step is a prerequisite for determining the next step.

1. Choose the content to analyze including the sample, the criteria, and the parameters (range of date).

The samples for this study were taken from 40 argumentative essay hooks of experienced writers. The term experienced means they are experts in their field which could come from different professions, i.e. writer, journalist, scientist, economist etc. The chosen media should also be a consideration in which it will influence the validity and reliability of the person. Thus, the media should have a high standard of editing which include The Jakarta post, New York Times, The Guardians, Inside Indonesia, The Washington Post, Quarterly Essay, and New Strait Times. The samples dates were taken from 2010-2020 publication.

2. Define the units of meaning and categories with their sub categories.

The unit of meaning will be coded is hook sentences at the first or two sentences in introductory paragraph. There are 4 set categories which include theme, number of words, type of sentences, and types of hook. The subcategories are elaborated as follows:

A1: Hook reflects the theme, A2: Hook doesn't reflect the theme

B1: Less than 10 words, B1: More than 10 words

C1: Simple Sentence, C2: Compound Sentence, C3: Complex Sentence

D1: Question, D2: Strong Statement, D3: Fact or Statistics, D4: Metaphor or Simile,

D5: Narration or story, D6: Quotation

\section{Develop a set of rules for coding.}

Coding involves organizing the units of meaning into the previously defined categories. Especially with more conceptual categories, it's important to clearly define the rules for what will and won't be included to ensure that all texts are coded consistently. Recording the rules makes the method more transparent and reliable. Rules include:

A1: Hook reflects the themes means the hook relatively tells what will be covered in the essay. A2: On the contrary of A1, A2 means doesn't reflect the essay discussion. 
B1: This hook has less than 10 words,

B2: This hook has more than 10 words.

C1: The hook contains one independent clause.

C2: The hook contains two independent clauses.

C3: The hook contains one independent clause with one or more dependent clauses.

D1: This hook is started with interrogative sentence with question mark.

D2: Strong statement means it is in a declarative state with using strong verbs or strong adjective sometimes with provoking idea or statement.

D3: Fact or statistics means the hook supply the number or fact of particular state.

D4: Metaphor and simile is figurative language by comparing someone's quality with animate or inanimate objects.

D5: It is a writer narration from his or her point of view.

D6: Quotation is someone's remark mentioned as a hook. It can be from famous or lay person. The quotation sentence is signified by question mark.

4. Code the text according to the rules.

In this stage, each text is recorded to all relevant data in the appropriate categories. The process is done manually. The next step is the unit of meaning is coded according to subcategories in step 3. Once all the sequence is done, all samples are collected in recapitulation table to compilation nad to count the frequency of each category and subcategories emerge in whole samples.

\section{Analyze the results and draw conclusions.}

Once coding is complete, the collected data is examined to find patterns and draw conclusions in response to research question. The result is discussed for interpretations of what the results mean, and make inferences about the result pattern and frequency.

\section{Discussion}

The analysis presented in this discussion will take different samples of hook sentences that represent the content analysis procedure of four categories. Regarding the ample amount of data, the complete analysis and samples can be downloaded in the following link .....

The first category to analyze is the theme. The following sample number 2 (by Sebastian Partogy, title: bourgeoisie ettiquete, published by The Jakarta Post) represents the analysis procedure.

Table 1. Theme Content Analysis

\begin{tabular}{llllll}
\hline $\begin{array}{c}\text { Meaning of Unit } \\
\text { (example of each category) }\end{array}$ & Codes & Subcategory & Category & Result \\
\hline "Careful of rich people," my late grandmother & The hook relatively & Hook reflects & Theme & A1 \\
used to warn me. "Once they get tired of tells what will be the theme & & \\
collecting stuff, they'd start collecting people. & covered in the essay. & & & & \\
\hline
\end{tabular}

On sample number 2, the essay discusses about the abuse of wealth and power by rich people. And the hook in table 1 gives a clue by giving a negative sentiment about rich people. The relation between the hook and the theme of essay is obtained by reading the whole essay and then match with the hook in the first sentence of introductory paragraph. This analysis process is employed to other 39 samples.

The next category to analyze is 'Number of Words'. It is suggested that the hook should be short (less than 10 words), which is logical, since most readers are lazy and they just have 7 second to decide whether an essay is interesting enough to read. Instead of testing the 
previous thesis, the study investigates whether the suggestion is used by writer to write the hook sentence. The following sample number 9 (by Karen B. Kaplan, title: let's meet again in five years, published by The New York Times) and sample number 28 (by Nick Chater, title: A Revolution in Our Sense of Self, published by The Guardian) represents the analysis procedure of this category.

Table 2. Number of Words Content Analysis

\begin{tabular}{llllll}
\hline \multicolumn{1}{c}{ Meaning of Unit } & \multicolumn{2}{c}{ Codes } & \multicolumn{1}{c}{ Subcategory } & \multicolumn{1}{c}{ Category } & Result \\
\hline $\begin{array}{l}\text { When I told Howard that we should meet again in } \\
\text { five years to see if we were meant to be together, I }\end{array}$ & $\begin{array}{l}\text { This hook has } \\
\text { more than } 10\end{array}$ & $\begin{array}{l}\text { More than } 10 \\
\text { words }\end{array}$ & $\begin{array}{l}\text { Number of } \\
\text { words }\end{array}$ & B 2 \\
thought I was just being practical. & words. & & & \\
\hline $\begin{array}{l}\text { At the climax of Anna Karenina, the heroine } \\
\text { throws herself under a train as it moves out of a }\end{array}$ & $\begin{array}{l}\text { This hook has } \\
\text { more than } \\
\text { station on the edge of Moscow. }\end{array}$ & $\begin{array}{l}\text { More than } 10 \\
\text { words. }\end{array}$ & & $\begin{array}{l}\text { Number of } \\
\text { words }\end{array}$ & B2 \\
\hline
\end{tabular}

Though it is arguable to say that short hooks are powerful and there is a tenet to say so. However, there are some people who is really interested in a particular topic i.e. politics or economics who will invest their time to read those topics regardless of boring and uninteresting opening. This means the number of words in hook is not really a top list consideration for them. Hence on table 2, the words that form the hook are more than 10 . The recapitulation of this category is presented in table number 7 .

The next category to discuss is 'types of sentence' which consist of three types: simple, compound, and complex sentences. The category could be four if added with compoundcomplex sentence, but this type is inserted into complex sentence category. The following samples number 6 (by Maggie Tiojakin, title: 'pause, rewind, and replay', published by The Jakarta Post) and 15 (by Varya Kluev, title: 'Pants on Fire', published by The New York Times) represent the analysis procedure of this category.

Table 3. Types of Sentences Content Analysis

\begin{tabular}{|c|c|c|c|c|}
\hline Meaning of unit & Codes & Subcategory & Category & Result \\
\hline I quit writing. & $\begin{array}{l}\text { The hook contains one } \\
\text { independent clause. }\end{array}$ & $\begin{array}{l}\text { Simple } \\
\text { Sentence }\end{array}$ & $\begin{array}{l}\text { Types of } \\
\text { Sentences }\end{array}$ & $\mathrm{C} 1$ \\
\hline $\begin{array}{l}\text { I never kissed the boy I liked bebind } \\
\text { the schoolyard fence that one March } \\
\text { morning. }\end{array}$ & $\begin{array}{l}\text { The hook contains one } \\
\text { independent clause. }\end{array}$ & $\begin{array}{l}\text { Simple } \\
\text { Sentence }\end{array}$ & $\begin{array}{l}\text { Types of } \\
\text { Sentences }\end{array}$ & C1 \\
\hline
\end{tabular}

The aforementioned samples are analyzed based on 'types of sentence category'. It means every samples will be analyzed to other three other categories: theme, number of words, and types of hook. The short recapitulation is presented in the table 4 which describes the subcategory analysis as a final conclusion for each category.

Table 4. Content Analysis of Four Categories

\begin{tabular}{|c|c|c|c|c|c|c|c|c|c|c|c|c|c|c|}
\hline \multirow{2}{*}{$\begin{array}{l}\text { The Hook } \\
\text { Sentence } \\
\text { Samples }\end{array}$} & \multicolumn{2}{|c|}{ Theme } & \multicolumn{2}{|c|}{$\begin{array}{l}\text { Number } \\
\text { of words }\end{array}$} & \multicolumn{3}{|c|}{$\begin{array}{c}\text { Types of } \\
\text { Sentences }\end{array}$} & \multicolumn{6}{|c|}{ Types of Hook } & \multirow[t]{2}{*}{$\begin{array}{c}\text { Preferences } \\
\text { Result }\end{array}$} \\
\hline & A1 & A2 & B1 & B2 & $\mathrm{C} 1$ & $\mathrm{C} 2$ & $\mathrm{C} 3$ & D1 & D2 & D3 & D4 & D5 & D6 & \\
\hline I quit writing. & A1 & $\mathrm{x}$ & B1 & $\mathrm{x}$ & C1 & $\mathrm{x}$ & $\mathrm{x}$ & $\mathrm{x}$ & $\mathrm{D} 2$ & $\mathrm{x}$ & $\mathrm{x}$ & $\mathrm{x}$ & $\mathrm{X}$ & A1B1C1D2 \\
\hline $\begin{array}{l}\text { I never kissed } \\
\text { the boy I liked } \\
\text { behind the } \\
\text { schoolyard fence } \\
\text { that one March } \\
\text { morning. }\end{array}$ & A1 & $\mathrm{x}$ & $\mathrm{x}$ & B2 & C1 & $\mathrm{x}$ & $\mathrm{x}$ & $\mathrm{x}$ & $\mathrm{x}$ & $\mathrm{x}$ & $\mathrm{x}$ & D5 & $\mathrm{x}$ & A1B2C1D5 \\
\hline
\end{tabular}


The reading of result sample number 6 in table 4 is as follow: A1B1C1D2 which can be interpreted as the hook sentence sample number 6 has characteristcis related to theme, with more than 10 words, written in simple sentence, and apply strong statement hook. The same reading is applied to sample number 15 .

The last category to analyze is 'types of hooks' which consists of Question Hook (D1), Strong Statement Hook (D2), Fact or Statistics Hook (D3), Metaphor or Simile Hook (D4), Narration or story Hook (D5), Quotation Hook (D6). It takes sample number 10 (by Laura Pritchett, title: 'No Sound, No Fury, No Marriage', published by The New York Times), 24 (by David Von Drehle, title: 'Vladimir Putin's Virus', published by The New York Times) represent the analysis procedure of this category.

Table 5. Types of Hook Content Analysis

\begin{tabular}{|c|c|c|c|c|}
\hline Meaning of unit & Codes & Subcategory & Category & Result \\
\hline $\begin{array}{l}\text { Three years ago, my busband and I broke up } \\
\text { after two decades of marriage. }\end{array}$ & $\begin{array}{l}\text { The writer narrates } \\
\text { from his or her point } \\
\text { of view. }\end{array}$ & $\begin{array}{l}\text { Narration or } \\
\text { story }\end{array}$ & $\begin{array}{l}\text { Types of } \\
\text { Hook }\end{array}$ & D5 \\
\hline $\begin{array}{l}\text { The president of the United States fires his } \\
\text { director of national intelligence after aides brief } \\
\text { a new Russian effort to interfere in the } 2020 \\
\text { election. }\end{array}$ & $\begin{array}{l}\text { The hook supplies } \\
\text { the number or fact of } \\
\text { particular state. }\end{array}$ & $\begin{array}{l}\text { Fact } \\
\text { Statistics }\end{array}$ & $\begin{array}{l}\text { Types of } \\
\text { Hooks }\end{array}$ & D3 \\
\hline
\end{tabular}

The following is the content analysis of 4 categories of samples number 10 and 24 .

Table 6. Types of Hook Content Analysis

\begin{tabular}{|c|c|c|c|c|c|c|c|c|c|c|c|c|c|c|}
\hline \multirow{2}{*}{$\begin{array}{l}\text { The Hook } \\
\text { Sentence } \\
\text { Samples }\end{array}$} & \multicolumn{2}{|c|}{ Theme } & \multicolumn{2}{|c|}{$\begin{array}{l}\text { Number } \\
\text { ofwords }\end{array}$} & \multicolumn{3}{|c|}{$\begin{array}{c}\text { Types of } \\
\text { Sentences }\end{array}$} & \multicolumn{6}{|c|}{ Types of Hook } & \multirow[t]{2}{*}{$\begin{array}{c}\text { Preferences } \\
\text { Result }\end{array}$} \\
\hline & A1 & A2 & B1 & B2 & $\overline{C 1}$ & $\mathrm{C} 2$ & $\mathrm{C} 3$ & D1 & $\mathrm{D} 2$ & D3 & D4 & D5 & D6 & \\
\hline $\begin{array}{l}\text { Three years ago, } \\
\text { my husband and } \\
\text { I broke up after } \\
\text { two decades of } \\
\text { marriage. }\end{array}$ & A1 & $\mathrm{x}$ & $\mathrm{x}$ & B2 & C1 & $\mathrm{x}$ & $\mathrm{x}$ & $\mathrm{x}$ & $\mathrm{x}$ & $\mathrm{x}$ & $\mathrm{x}$ & $\overline{\text { D5 }}$ & $\mathrm{x}$ & A1B2C1D5 \\
\hline $\begin{array}{l}\text { The president of } \\
\text { the United States } \\
\text { fires his director } \\
\text { of national } \\
\text { intelligence after } \\
\text { aides brief a new } \\
\text { Russian effort to } \\
\text { interfere in the } \\
2020 \text { election. }\end{array}$ & A1 & $\mathrm{x}$ & $\mathrm{x}$ & B2 & C1 & $\mathrm{x}$ & $\mathrm{x}$ & $\mathrm{x}$ & $\mathrm{x}$ & D3 & $\mathrm{x}$ & $\mathrm{x}$ & $\mathrm{x}$ & A1B2C1D3 \\
\hline
\end{tabular}

The reading of result sample number 10 in table 6 is as follow: A1B2C1D5 which can be interpreted as the hook sentence sample number10 has characteristcis related to theme, with more than 10 words, written in simple sentence, and apply narration or story hook. The same reading is applied to sample number 24 .

The following table 7 . presents the recapitulation of 40 samples including the preferences result.

Table 7. The Preferences Result of Hook Sentences

\begin{tabular}{|c|c|c|c|c|c|}
\hline $\begin{array}{l}\text { Hook } \\
\text { Sample }\end{array}$ & Theme & $\begin{array}{c}\text { Number } \\
\text { of } \\
\text { Words }\end{array}$ & $\begin{array}{l}\text { Type of } \\
\text { Sentence }\end{array}$ & $\begin{array}{l}\text { Type of } \\
\text { Hook }\end{array}$ & $\begin{array}{c}\text { Preferences } \\
\text { Result }\end{array}$ \\
\hline
\end{tabular}




\begin{tabular}{|c|c|c|c|c|c|c|c|c|c|c|c|c|c|c|}
\hline & A2 & A2 & B1 & B2 & C1 & $\mathrm{C} 2$ & C3 & D1 & D2 & D3 & D4 & D5 & D6 & \\
\hline Sample 1 & A1 & $\mathrm{x}$ & $\mathrm{x}$ & B2 & C1 & $\mathrm{x}$ & $\mathrm{x}$ & $\mathrm{x}$ & $\mathrm{x}$ & $\mathrm{x}$ & $\mathrm{x}$ & D5 & $\mathrm{x}$ & A1B2C1D5 \\
\hline Sample 2 & A1 & $\mathrm{x}$ & $\mathrm{x}$ & B2 & $\mathrm{x}$ & $\mathrm{x}$ & C3 & $\mathrm{x}$ & $\mathrm{x}$ & $\mathrm{x}$ & $\mathrm{x}$ & $\mathrm{x}$ & D6 & A1B2C3D6 \\
\hline Sample 3 & A1 & $\mathrm{x}$ & $\mathrm{x}$ & B2 & $\mathrm{x}$ & $\mathrm{x}$ & C3 & $\mathrm{x}$ & $\mathrm{x}$ & $\mathrm{x}$ & $\mathrm{x}$ & D5 & $\mathrm{x}$ & A1B2C3D5 \\
\hline Sample 4 & A1 & $\mathrm{x}$ & $\mathrm{x}$ & B2 & $\mathrm{x}$ & $\mathrm{x}$ & C3 & $\mathrm{x}$ & $\mathrm{x}$ & $\mathrm{x}$ & $\mathrm{x}$ & D5 & $\mathrm{x}$ & A1B2C3D5 \\
\hline Sample 5 & A1 & $\mathrm{x}$ & $\mathrm{x}$ & B2 & C1 & $\mathrm{x}$ & $\mathrm{x}$ & $\mathrm{x}$ & D2 & $\mathrm{x}$ & $\mathrm{x}$ & $\mathrm{x}$ & $\mathrm{x}$ & A1B2C1D2 \\
\hline Sample 6 & A1 & $\mathrm{x}$ & B1 & $\mathrm{x}$ & $\mathrm{C} 1$ & $\mathrm{x}$ & $\mathrm{x}$ & $\mathrm{x}$ & D2 & $\mathrm{x}$ & $\mathrm{x}$ & $\mathrm{x}$ & $\mathrm{x}$ & A1B1C1D2 \\
\hline Sample 7 & $\overline{\mathrm{A} 1}$ & $\mathrm{x}$ & $\mathrm{x}$ & B2 & $\mathrm{C} 1$ & $\mathrm{x}$ & $\mathrm{x}$ & $\mathrm{x}$ & $\mathrm{x}$ & $\mathrm{x}$ & $\mathrm{x}$ & D5 & $\mathrm{x}$ & A1B1C1D5 \\
\hline Sample 8 & A1 & $\mathrm{x}$ & $\mathrm{x}$ & B2 & C1 & $\mathrm{x}$ & $\mathrm{x}$ & $\mathrm{x}$ & $\mathrm{D} 2$ & $\mathrm{x}$ & $x$ & $\mathrm{x}$ & $\mathrm{x}$ & A1B1C1D2 \\
\hline Sample 9 & A1 & $\mathrm{x}$ & $\mathrm{x}$ & B2 & $\mathrm{x}$ & $\mathrm{x}$ & C3 & $\mathrm{x}$ & $\mathrm{x}$ & $\mathrm{x}$ & $\mathrm{x}$ & D5 & $\mathrm{x}$ & A1B2C3D5 \\
\hline Sample 10 & A1 & $\mathrm{x}$ & $x$ & B2 & $\overline{\mathrm{C} 1}$ & $\mathrm{x}$ & $\mathrm{x}$ & $\mathrm{x}$ & $x$ & $x$ & $x$ & D5 & $x$ & A1B2C1D5 \\
\hline Sample 11 & A1 & $\mathrm{x}$ & $\mathrm{x}$ & B2 & $\mathrm{x}$ & $\mathrm{x}$ & C3 & $\mathrm{x}$ & $x$ & D3 & $\mathrm{x}$ & $\mathrm{x}$ & $\mathrm{x}$ & A1B2C3D3 \\
\hline Sample 12 & A1 & $\mathrm{x}$ & $\mathrm{x}$ & B2 & $\mathrm{x}$ & $\mathrm{x}$ & $\mathrm{C} 3$ & $\mathrm{x}$ & $\mathrm{x}$ & $\mathrm{x}$ & $\mathrm{x}$ & D5 & $\mathrm{x}$ & A1B2C3D5 \\
\hline Sample 13 & A1 & $\mathrm{x}$ & B1 & $\mathrm{x}$ & C1 & $\mathrm{x}$ & $\mathrm{x}$ & $\mathrm{x}$ & $\mathrm{x}$ & $\mathrm{x}$ & $\mathrm{x}$ & D5 & $\mathrm{x}$ & 1D5 \\
\hline Sample 14 & A1 & $\mathrm{x}$ & $\mathrm{x}$ & B2 & $\mathrm{x}$ & $x$ & C3 & $\mathrm{x}$ & $x$ & $x$ & $x$ & D5 & $x$ & C1D5 \\
\hline Sample 15 & A1 & $\mathrm{x}$ & $\mathrm{x}$ & B2 & C1 & $\mathrm{x}$ & $\mathrm{x}$ & $\mathrm{x}$ & $\mathrm{x}$ & $\mathrm{x}$ & $\mathrm{x}$ & D5 & $\mathrm{x}$ & A1B2C1D5 \\
\hline Sample 16 & A1 & $\mathrm{x}$ & $\mathrm{x}$ & B2 & $\mathrm{x}$ & $\mathrm{x}$ & $\mathrm{C} 3$ & $\mathrm{x}$ & $\mathrm{x}$ & $\mathrm{x}$ & $\mathrm{x}$ & D5 & $\mathrm{x}$ & A1B2C3D5 \\
\hline Sample 17 & A1 & $\mathrm{x}$ & $\mathrm{x}$ & B2 & $\mathrm{x}$ & $\mathrm{x}$ & C3 & $\mathrm{x}$ & $\mathrm{x}$ & $\mathrm{x}$ & $\mathrm{x}$ & D5 & $\mathrm{x}$ & A1B2C3D5 \\
\hline Sample 18 & A1 & $\mathrm{x}$ & $\mathrm{x}$ & B2 & C1 & $\mathrm{x}$ & $\mathrm{x}$ & $\mathrm{x}$ & $\mathrm{x}$ & $\mathrm{x}$ & $\mathrm{x}$ & D5 & $\mathrm{x}$ & A1B2C1D5 \\
\hline Sample 19 & A1 & $\mathrm{x}$ & $\mathrm{x}$ & B2 & $\mathrm{x}$ & $\mathrm{x}$ & $\mathrm{C} 3$ & $\mathrm{x}$ & $\mathrm{x}$ & $\mathrm{x}$ & $\mathrm{x}$ & D5 & $\mathrm{x}$ & A1B2C3D5 \\
\hline Sample 20 & A1 & $\mathrm{x}$ & $\mathrm{x}$ & B2 & $\mathrm{x}$ & $\mathrm{x}$ & $\mathrm{C} 3$ & $\mathrm{x}$ & $\mathrm{x}$ & $\mathrm{x}$ & $\mathrm{x}$ & D5 & $\mathrm{x}$ & A1B2C3D5 \\
\hline Sample 21 & A1 & $\mathrm{x}$ & $\mathrm{x}$ & B2 & $\mathrm{X}$ & $\mathrm{x}$ & $\mathrm{C} 3$ & $\mathrm{x}$ & $\mathrm{x}$ & $\mathrm{x}$ & $\mathrm{x}$ & D5 & $\mathrm{x}$ & A1B2C1D5 \\
\hline Sample 22 & A1 & $\mathrm{x}$ & $\mathrm{x}$ & B2 & C1 & $\mathrm{x}$ & $\mathrm{x}$ & $\mathrm{x}$ & D2 & $\mathrm{x}$ & $\mathrm{x}$ & $\mathrm{x}$ & $\mathrm{x}$ & A1B2C1D2 \\
\hline Sample 23 & A1 & $\mathrm{x}$ & $\mathrm{x}$ & B2 & $\mathrm{x}$ & $\mathrm{x}$ & $\mathrm{C} 3$ & $\mathrm{x}$ & $\mathrm{x}$ & D3 & $\mathrm{x}$ & $\mathrm{x}$ & $\mathrm{x}$ & A1B2C3D3 \\
\hline Sample 24 & A1 & $\mathrm{x}$ & $\mathrm{x}$ & B2 & C1 & $\mathrm{x}$ & $\mathrm{x}$ & $\mathrm{x}$ & $\mathrm{x}$ & D3 & $\mathrm{x}$ & $\mathrm{x}$ & $\mathrm{x}$ & A1B2C1D3 \\
\hline Sample 25 & A1 & $\mathrm{x}$ & B1 & $\mathrm{x}$ & $\mathrm{C} 1$ & $\mathrm{x}$ & $\mathrm{x}$ & $\mathrm{x}$ & D2 & $\mathrm{x}$ & $x$ & $\mathrm{x}$ & $x$ & A1B1C1D2 \\
\hline Sample 26 & A1 & $\mathrm{x}$ & $\mathrm{x}$ & B2 & $\mathrm{C} 1$ & $\mathrm{x}$ & $\mathrm{x}$ & $\mathrm{x}$ & $\mathrm{x}$ & $\mathrm{x}$ & $\mathrm{x}$ & D5 & $\mathrm{x}$ & A1B2C1D5 \\
\hline Sample 27 & A1 & $\mathrm{x}$ & $x$ & B2 & $\mathrm{C} 1$ & $\mathrm{x}$ & $\mathrm{x}$ & $\mathrm{x}$ & D2 & $\mathrm{x}$ & $\mathrm{x}$ & $\mathrm{x}$ & $\mathrm{x}$ & A1B2C1D2 \\
\hline Sample 28 & A1 & $\mathrm{x}$ & $\mathrm{x}$ & B2 & $\mathrm{C} 1$ & $\mathrm{x}$ & $\mathrm{x}$ & $\mathrm{x}$ & $\mathrm{x}$ & $\mathrm{x}$ & $\mathrm{x}$ & D5 & $\mathrm{x}$ & A1B2C1D5 \\
\hline Sample 29 & A1 & $\mathrm{x}$ & B1 & $\mathrm{x}$ & C1 & $\mathrm{x}$ & $\mathrm{x}$ & $\mathrm{x}$ & $\mathrm{D} 2$ & $\mathrm{x}$ & $\mathrm{x}$ & $\mathrm{x}$ & $\mathrm{x}$ & A1B1C1D2 \\
\hline Sample 30 & A1 & $\mathrm{x}$ & B1 & $\mathrm{x}$ & C1 & $\mathrm{x}$ & $\mathrm{x}$ & $\mathrm{x}$ & D2 & $\mathrm{x}$ & $\mathrm{x}$ & $\mathrm{x}$ & $\mathrm{x}$ & A1B1C1D2 \\
\hline Sample 31 & A1 & $\mathrm{x}$ & B1 & $\mathrm{X}$ & C1 & $\mathrm{x}$ & $\mathrm{x}$ & $\mathrm{x}$ & D2 & $\mathrm{x}$ & $\mathrm{x}$ & $\mathrm{x}$ & $\mathrm{x}$ & A1B1C1D2 \\
\hline Sample 32 & A1 & $\mathrm{x}$ & $\mathrm{x}$ & B2 & $\mathrm{x}$ & $\mathrm{x}$ & $\mathrm{C} 3$ & $\mathrm{x}$ & $\mathrm{x}$ & $\mathrm{x}$ & $\mathrm{x}$ & D5 & $\mathrm{x}$ & 1B2C3D5 \\
\hline le 33 & A1 & $\mathrm{x}$ & $\mathrm{x}$ & B2 & $\mathrm{x}$ & $\mathrm{C} 2$ & $\mathrm{x}$ & $\mathrm{x}$ & $\mathrm{x}$ & $\mathrm{x}$ & $\mathrm{x}$ & D5 & $\mathrm{x}$ & 2C2D5 \\
\hline Sample 34 & A1 & $\mathrm{x}$ & $\mathrm{x}$ & B2 & $\mathrm{C} 1$ & $\mathrm{x}$ & $\mathrm{x}$ & $\mathrm{x}$ & $\mathrm{x}$ & D3 & $\mathrm{x}$ & $\mathrm{x}$ & $\mathrm{x}$ & $32 \mathrm{C} 1 \mathrm{D} 3$ \\
\hline Sample 35 & A1 & $\mathrm{x}$ & $\mathrm{x}$ & B2 & $\mathrm{x}$ & $\mathrm{x}$ & $\mathrm{C} 3$ & $\mathrm{x}$ & $\mathrm{x}$ & $x$ & $x$ & D5 & $x$ & B2C3D5 \\
\hline Sample 36 & A1 & $\mathrm{x}$ & $\mathrm{x}$ & B2 & C1 & $\mathrm{x}$ & $\mathrm{x}$ & $\mathrm{x}$ & D2 & $\mathrm{x}$ & $\mathrm{x}$ & $\mathrm{x}$ & $\mathrm{x}$ & A1B2C1D2 \\
\hline Sample 37 & A1 & $\mathrm{x}$ & $\mathrm{x}$ & B2 & $\mathrm{C} 1$ & $\mathrm{x}$ & $\mathrm{x}$ & $\mathrm{x}$ & $\mathrm{D} 2$ & $\mathrm{x}$ & $\mathrm{x}$ & $\mathrm{x}$ & $\mathrm{x}$ & A1B2C1D2 \\
\hline Sample 38 & A1 & $\mathrm{x}$ & $\mathrm{x}$ & B2 & C1 & $\mathrm{x}$ & $\mathrm{x}$ & $\mathrm{x}$ & $\mathrm{x}$ & $\mathrm{x}$ & $\mathrm{x}$ & D5 & $\mathrm{x}$ & A1B2C1D5 \\
\hline Sample 39 & A1 & $\mathrm{x}$ & $\mathrm{x}$ & B2 & $\mathrm{x}$ & $\mathrm{x}$ & $\mathrm{C} 3$ & $\mathrm{x}$ & $\mathrm{D} 2$ & $\mathrm{x}$ & $\mathrm{x}$ & $\mathrm{x}$ & $\mathrm{x}$ & $\mathrm{A} 1 \mathrm{~B} 2 \mathrm{C} 3 \mathrm{D} 2$ \\
\hline Sample 40 & A1 & $\mathrm{x}$ & $\mathrm{x}$ & B2 & C1 & $\mathrm{x}$ & $\mathrm{x}$ & $\mathrm{x}$ & $\mathrm{x}$ & $\mathrm{x}$ & $x$ & D5 & $\mathrm{x}$ & A1B2C1D5 \\
\hline Total & 40 & 0 & 6 & 34 & 23 & 1 & 16 & 0 & 12 & 4 & 0 & 23 & 1 & \\
\hline
\end{tabular}

It is not really surprising that all 40 hook samples reflect the theme of the essay (A1). The hook relatively covers, covertly or overtly, the idea of the essay eventhough it sometimes touches just the tip of idea of the essay. This finding also indicates that most writer really employs the theory into practice which means they to use hook-related-theme as hook sentence. They introduce what will be covered in the essay by giving the clue to the reader in the hook sentence. Though the title of the essay should depict what will be covered, but the consistent use of hook-related content just makes the essay more coherent with the overall theme.

Of 40 samples, 34 hook sentences contain more than 10 than words which is a surprising fact. It means the sentences are long enough and more than half contain more than 
20 words, which is three or four lines. It seems they don't think there must be word limitation for making hook sentence short. The other probability is they think hook sentences are not necessarily short because there is no convention among writers to make it so. From the reading of the preferences it is obvious many writers choose not to be restrained by the number of words, but rather to the relevance of the hook sentence and the established theme in the essay.

In type of sentence category, it is noticeable that there is a relative balance use of the simple sentences (23 usage) and complex sentences (16 usage). Variations in usage of both types which are not too distinguished indirectly indicate that the authors do not put importance the type of sentence use regardless of the essay genre itself. this states that the authors' preference applies to all types of sentences eventhough the compound sentence (1 usage) is not a favourite of the authors.

The last category, the hook type, shows that the preferences of the writers are narrative hook (23 usage) which is more than a half of samples (40 samples). This can be interpreted that many writers tend to use their personal experience to use as a hook. Though other type of hook like strong statement (12 usages) and fact or statistics (4 usages) has been used as hook, but the number is not significant to balance narrative hook.

\section{Result}

From the table 7. reading and its following elaboration, the writers' preferences of hook sentences are all related to theme of the essay with long sentences and most of them use narrative hook as an opener. There is no tendency for writer to use three types of sentences as dominant form of writing. The finding also tells that short sentences as suggested tenet to write hook sentences is not found in most of the essay. This reveals the suggested model is not a convention among writers.

\section{References}

Bailey, S. (2011). Academic Writing: A Handbook for International Students (3rd ed.). London: Routledge.

Buckham, M. (2014). Writing Active Hooks: Action, Emotion, Surprise and More. Cantwell Publishing.

Cascio, C. (n.d.). Attention Grabbers to Use when Writing an Essay. (online), (education.seattlepi.com/attention-grabbers-use-writing-essay-3435.html), diakses $5 \mathrm{Mei}$ 2020

Davis, S. (2019). 7 Sensational Essay Hooks That Grab Readers' Attention. (online), (www.academicwritingsucces.cm/7-sensational-essay-hooks), diakses 24 Mei 2020

Hanski, M. (2019). How To Write a Good Hook for Your Essay. (online), (bid4papers.com/blog/hook-for-essay), diakses 20 Mei 2020

Hills, A. (2018). Good Attention Getters for Essays with Examples. (online), (owlcation.com/humanities/Good-Attention-Getter), diakses 2 mei 2020

Hsieh, H.-F., \& Shannon, S. (2005). Three Approaches to Qualitative Content Analysis. Qualitative Health Reseach, 15, 1277-1288.

Jordan, R. R. (2003). Academic Writing Course. London: Pearson Education Limited.

Knowles, E. (2005). The Oxford Dictionary of Phrase and Fable (2nd ed). London: Oxford University Press. 
Krippendorff, K. (2013). Content Analysis: An Introduction to its Methodology. Thousand Oaks, CA: Sage.

Merriam-Webster. (2019). The Merriam-Webster Dictionary, newest edition. Massachusetts: Merriam-Webster Inc.

Myers, Jack. Wukash, D. C. (2009). Dictionary of Poetic Terms (New ed). Denton: University of North Texas Press.

Neuendorf, K. A. (2016). The Content Analysis Guidebook. Thousand Oaks, CA: Sage.

Oshima, A. \& A. H. (2006). Writing Academic English (4th ed.). London: Pearson Longman.

Punter, D. (2007). Metaphor. London: Routledge.

Schreier, M. (2012). Qualitative Content Analysis in Practice. Thousand Oaks, CA: Sage. 